\title{
THE RELATIONSHIP BETWEEN WEIGHT GAIN IN PREGNANCY AND PREECLAMPSIA
}

\author{
Hemi Fitriani $^{1}$, Tria Firza Kumala ${ }^{1}$,Nia Rosmiati ${ }^{1}$ \\ ${ }^{1}$ Sekolah Tinggi Ilmu Kesehatan Jenderal Ahmad Yani Cimahi \\ Corresponding email: hemi.ftrn@yahoo.com, tiafirza@yahoo.com
}

\begin{abstract}
Preeclampsia is the second leading cause of maternal death in Indonesia. several risk factors include primigravida, primiparity, hyperplacentosis, family history of preeclampsia/eclampsia, kidney disease, and weight gain. The purpose of this study was to identify the relationship of weight gain during pregnancy with the incidence of preeclampsia in the puerperium of Cimahi City Hospital. This study was conducted using a cross-sectional design. The total sample included 72 pregnant women who selected using purposive sampling techniques. Data collection techniques using observation and interviews. The instruments used were observation sheets and interview sheets. The study was conducted from May to June 2019. Data were analyzed using frequency distribution for univariate analysis and chi-square test for bivariate analysis. This study was approved by the research ethics committee of Sekolah Tinggi Ilmu Kesehatan Jenderal Achmad Yani More than one-third of participants had weight gain more than normal $38.9 \%$ of respondents. There was a significant relationship between weight gain during pregnancy and the incidence of preeclampsia with $\mathrm{p}$-value $=0.033 \mathrm{p}$-value $<\alpha(\alpha=0.05)$. The risk of preeclampsia is faced by women who less or more weight gain during pregnancy. It is expected that health workers, especially maternity nurses, would prevent the incidence of preeclampsia by conducting health education and motivation about maintaining weight during pregnancy.
\end{abstract}

Keywords: Weight Gain, Body Mass Index (BMI), Pregnancy, Preeclampsia

\section{INTRODUCTION}

Preeclampsia is the second leading cause of maternal death in Indonesia. The first was hemorrhage (28\%) and followed by preeclampsia (24\%), and $11 \%$ infection (MOH RI, 2016). The prevalence of preeclampsia is still high in West Java Province, which is $25 \%$ (Ministry of Health Republic of Indonesia, 2015). The Cimahi city is part of West Java also has a prevalence of 25\% preeclampsia (MOH West Java, 2016). Preeclampsia needs adequate interventions and observations because of interferes fetal growth and threatens both maternal and fetal lives. Preeclampsia causes stunted fetal growth, premature birth, and low birth weight (Bobak, Lowdermilk \& Jensen, 2012). In women, preeclampsia causes seizures. During seizures, brain activity is disrupted, causing blank vision, body shaking, decreased the level of consciousness, tongue biting and bone fractures (Reeder \& Sharon J, 2012). Preeclampsia can cause hypoxia intrapartum. Worse consequences of preeclampsia are maternal and fetal death (Baiti and Cahyanti, 2018). 
Maternal and fetal death rates due to preeclampsia can be reduced through various health interventions, including illness prevention, early detection, and therapy. Prevention is done when women and their spouses knowing the risk factors for preeclampsia. Dhora and Rachmah (2014) state that risk factors for preeclampsia include weight gain, age, and gravida. According to Nurhasanah \& Indriani (2016), several risk factors include primigravida, primiparity, hyperplacentosis (molahidatidosa, multiple pregnancies, diabetes mellitus, large baby), family history of preeclampsia/eclampsia, and kidney disease since before pregnancy. Another risk factor is weight gain. This factor can be controlled and managed by pregnant women themselves. Controlling weight gain by diet modification. Pregnant women manage their intake of nutrients to eat (Novi, et al, 2016). Efforts to gain weight during pregnancy related to the normal. Weight gain that exceeds the provisions or is less than the normal is a risk factor for preeclampsia. Weight gain during pregnancy depends on the body mass index (BMI) before pregnancy.

Table 1 Weight Gain Recommended during pregnancy

\begin{tabular}{l|l}
\hline IMT Sebelum Hamil & Kenaikan Berat Badan \\
\hline$<17,00=$ Thin & $14-20 \mathrm{Kg}$ \\
\cline { 1 - 2 } $17,0-18,5=$ Thin & \\
\hline$>18,5-25,0=$ Normal & $12,5-17,5 \mathrm{Kg}$ \\
\hline$>25,0-27,0=$ Fatty & $7,5 \mathrm{Kg}$ \\
\hline$>27,0=$ Fatty & \\
\hline
\end{tabular}

(Supariasa et al, 2012 \& Mintarsih, 2016)

Previous research by Lipoeto.N.I et al (2016) states that BMI in pregnant and overweight patients is one of the risk factors for preeclampsia. The study shows a significant relationship between BMI with the incidence of preeclampsia in RSUP Dr. M. Djamil Padang. Andriani, C (2016) also mentioned a significant relationship between BMI and the incidence of preeclampsia. Nursal et al (2014) said in Dr. M. Djamil Padang Hospital, obese pregnant women have 4 times the risk of developing preeclampsia. This study aimed to assess weight gain during pregnancy based on BMI 
before becoming pregnant with the incidence of preeclampsia, whereas previous studies have only linked Body Mass Index (BMI) before pregnancy without looking at weight gain during pregnancy.

Based on the results of a preliminary study at Dustira Hospital on February e20 2019, data on the number of pregnant women experiencing preeclampsia in 2016 and 2017 were the same, namely 124 patients, and 2018 decreased to 80 patients. But the number is high compared to other diseases. From interviews conducted on 3 pregnant women and 7 postpartum mothers, they said that the excess weight gain from BMI was $19 \mathrm{~kg}$, had preeclampsia with TD $130 / 80-140$ / 90 mmHg, 1 mother gained more than $19 \mathrm{~kg}$ but did not preeclampsia, pregnant women with weight gain according to BMI do not experience preeclampsia with TD $110 / 80-120 / 80 \mathrm{mmHg}$. The purpose of this study was to identify the relationship of weight gain during pregnancy with the incidence of preeclampsia in the puerperium of Cimahi City Hospital.

\section{METHODS}

The design of this study was the Analytical Survey, with Cross-Sectional design. The population in this study was postpartum women in the puerperal room of Dustira Hospital in Cimahi City, from August 2018 to January 2019 with 130 people. The sample consisted of 72 respondents chosen using the purposive sampling technique. Inclusion criteria included postpartum women for a maximum of 48 hours, exclusion criteria included postpartum women who experienced speech disorders and seizures. Data was collected using observation form, the data source was patient book record. The stages of data processing included editing, coding, entry, and cleaning. The univariate analysis using frequency distribution, and Bivariate analysis used the chisquare (x2) test. The study was located at Burangrang Room, Dustira Hospital, Cimahi City. The study was conducted from May-June 2019. This research has received ethical approval from the research ethics committee of the College of Health Science Jenderal Achmad Yani with number 65 / KEPK / V / 2019. 


\section{RESULTS}

The result of this study is presented in table 1- 3

Table 2 Weight Gain percentages

\begin{tabular}{|c|c|c|c|}
\hline $\begin{array}{l}\text { Weight Gain } \\
\text { Pregnancy }\end{array}$ & During & Frequency & $\%$ \\
\hline less than normal & & 22 & 30,6 \\
\hline normal & & 22 & 30,6 \\
\hline More than normal & & 28 & 38,9 \\
\hline Total & & 72 & 100 \\
\hline
\end{tabular}

Table 2 presents the percentage of pregnant women's weight gain, more than one-third of participants had weight gain more than normal $38.9 \%$ of respondents.

Tabel 3 Women with Preeclampsia

\begin{tabular}{lll}
\hline Preeclampsia & Frequency & \% \\
\hline Yes & 33 & 45,8 \\
No & 39 & 54,2 \\
\hline Total & 72 & 100
\end{tabular}

Table 3 explains that the incidence of preeclampsia occurred as much as $45.8 \%$.

Table 4 Relationship Between Weight Gain During Pregnancy and the Incidence of Preeclampsia

\begin{tabular}{llllllll}
\hline $\begin{array}{l}\text { Weight } \\
\text { During Pregnancy }\end{array}$ & $\begin{array}{l}\text { Yes } \\
\text { Mreeclampsia }\end{array}$ & No & & & Total & P- \\
& N & $\%$ & N & $\%$ & N & $\%$ & Value \\
\hline less than Normal & 5 & $22,7 \%$ & 17 & $77,3 \%$ & 22 & 100 & \\
Normal & 12 & $54,5 \%$ & 10 & $45,5 \%$ & 22 & 100 & 0,033 \\
More than Normal & 16 & $57,1 \%$ & 12 & $42,9 \%$ & 28 & 100 & \\
\hline Total & 33 & $45,8 \%$ & 39 & $54,2 \%$ & 72 & 100 & \\
\hline
\end{tabular}

Table 4 The chi-square Pearson statistical test results found there is a significant relationship between weight gain during pregnancy and the incidence of preeclampsia with $\mathrm{p}$-value $=0.033 \mathrm{p}$-value $<\alpha(\alpha=0.05)$. 


\section{DISCUSSION}

The results found that there is a relationship between weight gain during pregnancy and preeclampsia. This is explained by Martaadisoebrata (2013), that women's less weight gain during pregnancy causes unbalanced nutrient substances in cells so that there is a disruption in the process of trophoblast invasion which eventually triggers systemic vasospasm and systemic preeclampsia. Obesity during pregnancy also causes preeclampsia by the same mechanism. Obesity in pregnancy illustrates a lot of fat in the body's cells. This condition disrupts the process of trophoblast invasion which eventually triggers the occurrence of systemic vasospasm of the blood vessels and preeclampsia.

Martaadisoebrata (2013) mentions that vasospasm is the beginning sign of preeclampsia. Vasospasm is a result of the failure of trophoblast invasion into the smooth muscle layers of blood vessels, immunological reactions, and free radicals. All this would cause damage / endothelial injury, and cause an imbalance between vasoconstrictor levels (endothelin, thromboxane, angiotensin) and vasodilators (nitric oxide, prostacyclin), and problems of the blood clotting system. The results also showed that women who gained more and less weight than normal did not experience preeclampsia. This may be because weight gain is not the only factors causing preeclampsia, there are other factors such as immunological, genetic/familial, gravidity, age and disease history. These factors have a normal value so it is not too risky for the occurrence of preeclampsia.

The results showed the more weight gain the more risk of preeclampsia. It maybe happened because someone who in obesity, the endothelial dysfunction would occur, which causes endothelial damage and the risk of preeclampsia, increasingly. In women with preeclampsia, uteroplacental artery lesions are found. This microscopic lesion is similar to atherosclerosis. The fat buildup is also found glomerulus in patients with preeclampsia. The presence of glomerular lesions causes proteinuria. A person with obesity has a risk of preeclampsia 2.8 times higher than someone who has an ideal body weight (Wafiyatunisa, 2016). 


\section{CONCLUSION}

The risk of preeclampsia is faced by women who less or more weight gain during pregnancy. It is expected that health workers, especially maternity nurses, would prevent the incidence of preeclampsia by conducting health education and motivation about maintaining weight during pregnancy.

\section{REFERENCES}

Andriani, C. (2016). Hubungan Indeks Massa Tubuh dengan Kejadian Preeklampsia di RSUP Dr. M. Djami Padang. Jurnal Kesehatan Andalas, 5(1), 2016 : 173-178

Baiti, b. N., \& cahyanti, R. D. (2018). Kualitas rujukan ibu hamil dengan preeklampsia/eklampsia di UGD obstetri-ginekologi rsup dr. Kariadi Semarang periode tahun 2013-2016. Jurnal kedokteran diponegoro, 7(1), 81-99.

Bobak, Lowdermilk \& Jensen.(2012). Buku Ajar Keperawatan Maternitas. Jakarta: EGC

Departemen Kesehatan Jabar. (2015). Profil Kesehatan Jawa Barat Tahun 2015. Diperoleh dari http://Deskes-Jabar.go.id. Diunduh pada 03 Febuari 2019

Departemen Kesehatan Jabar. (2016). Profil Kesehatan Jawa Barat Tahun 2016. Diperoleh dari http://Deskes-Jabar.go.id. Diunduh pada 03 Febuari 2019

Departemen Kesehatan RI. (2015). Profil Kesehatan Indonesia Tahun 2015.http://www.depkes.go.id/resources/download/pusdatin/profil-kesehatanindonesia/profil-kesehatan-Indonesia-2015.pdf. Diunduh 03 Febuari 2019

Departemen Kesehatan RI. (2016). Profil Kesehatan Indonesia Tahun 2016.http://www.depkes.go.id/resources/download/pusdatin/profil-kesehatanindonesia/Profil-Kesehatan-Indonesia-tahun-2016.pdf. Diunduh tanggal 03 Febuari 2019

Departemen Kesehatan RI. (2017). Profil Kesehatan Indonesia Tahun 2017.http://www.depkes.go.id/resources/download/pusdatin/profil-kesehatanindonesia/Profil-Kesehatan-Indonesia-tahun-2017.pdf. Diunduh tanggal 03 Febuari 2019

Palupi, D. D., \& Indawati, R. (2014). Faktor Risiko Kematian Ibu dengan Preeklampsia/Eklampsia dan Perdarahan di Provinsi Jawa Timur. Jurnal Biometrika dan Kependudukan, 3(2), 107-113.

Kemenkes RI. (2015). Survey Demografi Kesehatan Indonesia. Jakarta :Kemenkes RI

Martaadisoebrata D (2013). Obstetri Patologi Ilmu Kesehatan Reproduksi. Edisi 3.Penerbit Buku Kedokteran EGC: Jakarta 
Mitayani. (2009). Asuhan keperawatan Maternitas. Salemba Medika:Jakarta.

Notoatmodjo, S. (2010). Metodologi Penelitian Kesehatan. Jakarta :Rineka Cipta

Novi, et al. (2016). Determinan gangguan hipertensi kehamilan di Indonesia. Berita Kedokteran Masyarakat, 32(9).

Lipoeto.N.I ,et al. (2016) HubunganIndeks Massa Tubuh dengan Kejadian Preeklampsia di RSUP Dr. M. Djami Padang. Jurnal Kesehatan Andalas, 5(1), 2016 : 173-178

Nurhasanah, D. N., \& Indriani, I. (2016). Faktor-faktor yang berhubungan dengan kejadian preeklamsia pada ibu hamil di RSUD panembahan senopati bantul tahun 2016. (Doctoral dissertation, Universitas' Aisyiyah Yogyakarta).

Nursal, et al. (2014). Faktor-faktor Kejadian preeclampsia Pada Ibu Hamil Di RSUP DR. M. Djamil Padang Tahun 2014. Jurnal Kesehatan Masyarakat Andalas : Program Studi S-I Kesehatan Masyarakat Fakultas Kesehatan Masyarakat Universitas Andalas.

Reeder \& Sharon J. (2012). Keperawatan Maternitas Kesehatan Wanita, Bayi, dan keluarga. Jakarta: EGC.

Mintarsih, S.(2016). Berat Badan Dan Nurtisi Pada Wanita Hamil. Surakarta :Akper PKU Muhammadiyah

Supariasadkk, (2012). Penilaian Status Gizi. Penerbit Buku Kedokteran. EGC: Jakarta 